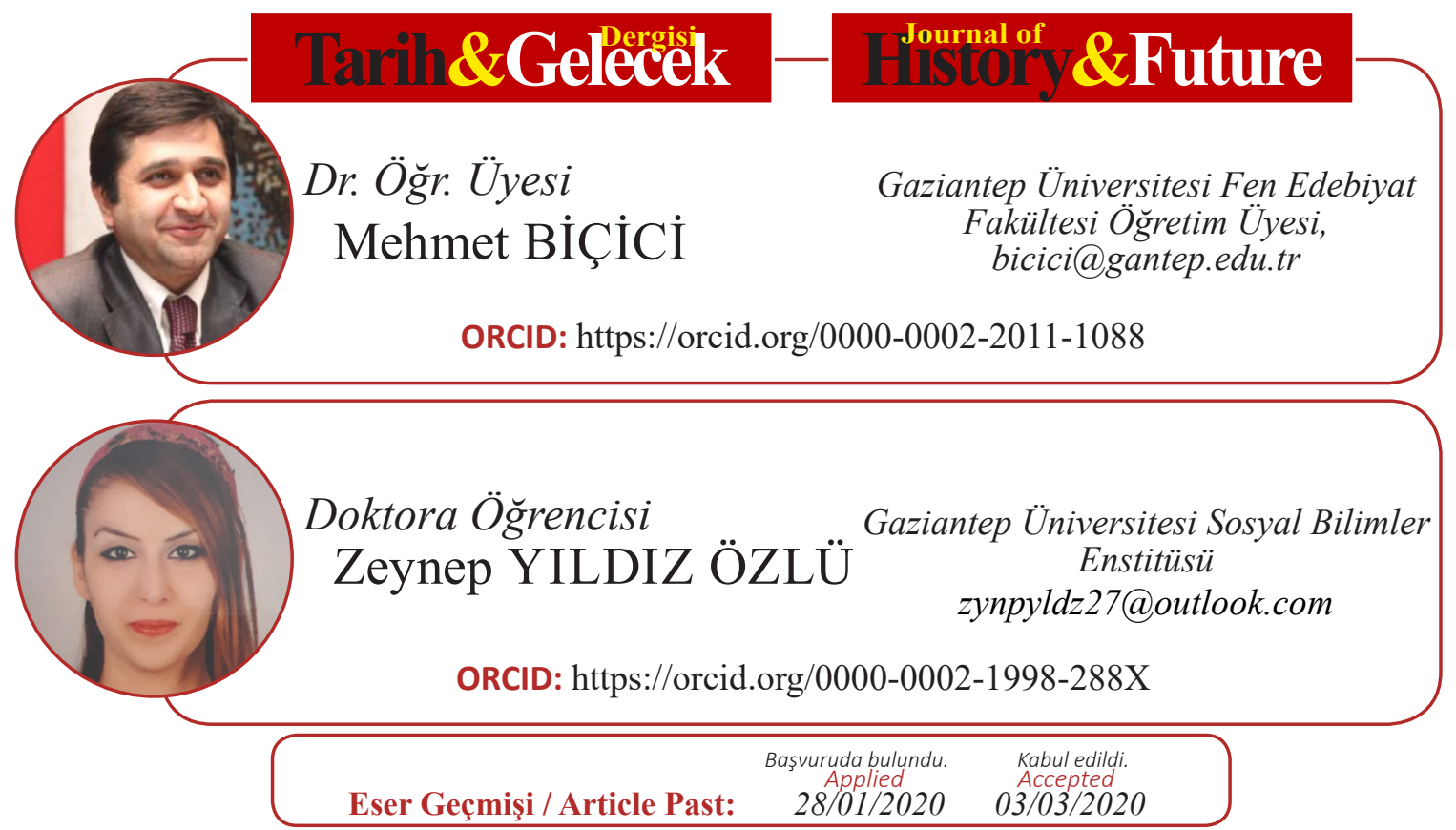

Araştırma Makalesi

DOI: http://dx.doi.org/10.21551/jhf.681313

Research Paper

Orjinal Makale / Orginal Paper

\title{
Harf İnkılâbı Üzerine Türkiye Büyük Millet Meclisi’nde Çıkan Tartışmalar Ve Karşıt Görüşler
}

\author{
Debates and Opposing Views in the Turkish Grand National Assembly on \\ the Letter Revolution
}

\section{Öz}

Harf İnkılabı tartışmaları Osmanlı Devleti'nde Tanzimat'ın ilanı sonrasında başlamıştır. Arap alfabesi Türk Diline uyarlanmaya çalışılmıs fakat okuma ve yazma da birçok sorunla karşılaşılmıştır. Bir süre sonra aydın kesimler tarafindan bu konu tartışılmaya başlanmıştır. Illk olarak 1862'de Münif Pasa, "Cemiyet-i İlmiye-i Osmaniye'de" verdiği konferansta alfabe meselesini ele almıştır. Arap harfleriyle okuma-yazmanın zor olduğundan kolaylaştırmak için harflerin islah edilmesi gerektiği fikrini ortaya atmıştır. Bazı aydın kesim ise Arap harflerinin tamamen kaldırllması gerektiği söylese de birçok aydın harflerin islahı fikrinde birleşmiştir. Ittihat ve Terakki döneminde Enver Paşa, bu soruna "Enveri" yazısı adını verdiği alfabe ile Arap harflerinde bazı düzenlemeler yaparak soruna çözüm bulmaya çalışmıştır. I. Dünya Savaşı ve ardından Kurtuluş Savaşı dönemlerinde alfabe tartısmaları durmuştur. Ancak Cumhuriyet'in ilanı sonrasında Harf İnkılabı tartışmaları devam etmiştir. Özellikle 1924 yılında Şükrü Saraçoğlu'nun Harf İnkılabı hakkındaki konuşması meseleyi tekrar gündeme getirmişstir. Meclis içinde sesler yükselmeye basslamıştır. Inkılabı destekleyen ve karşı çıkanlar meclis dışında da basın yoluyla düşüncelerini ifade etmişlerdir. Bu konuda çeşitli makale, kitaplar yayınlamışlardır. Mustafa Kemal Atatürk, bu tartışmalarl yakından inceleyerek zamanın ve sartların olgunlaştığı bir dönemde Harf Inkılabını gerçekleştirmiştir. Harf inkılâbının gerçekleştirilmesi okur-yazar oranının artması, basın yayın hayatının canlanması, toplumun çağdaşlaşmaSl, kültürel değişimin hızlanmast ve millet bilincinin yerleşmesinde de etkili olmuştur. Bu makalenin amact; Tanzimat'tan itibaren süregelen Cumhuriyet'in ilanı ile de şiddetlenen harf inkılabı tartışmalarını ortaya koyup yeni bir bakış açısı kazandırmaktır.

Anahtar Kelimeler: Harf İnkılabı, Devrim, TBMM’ deki Tartışmalar, Arap Alfabesi, Latin Alfabesi

ATIF: BİÇİCİ Mehmet, YILDIZ ÖZLÜ Zeynep, "Harf İnkılâbı Üzerine Türkiye Büyük Millet Meclisi’nde Çıkan Tartışmalar Ve Karşıt Görüşler”, Tarih ve Gelecek Dergisi, 6/1 (Mart 2020), s. (180-197)

CITE: BİÇİCİ Mehmet, YILDIZ ÖZLÜ Zeynep, "Debates And Opposing Views In The Turkish Grand National Assembly On The Letter Revolution”, Journal of History and Future, 6/1 (March 2020), pp. (180-197) 


\begin{abstract}
The discussions on alphabet revolution started in Ottoman Empire after Tanzimat. Arabis alphabet was adapted to Turkish language but reading and writing was faced with many problems. After then, this issue was started to be discussed by entellectuel people. Firstly, in 1862, Münif Pasha dealt with the alphabet issue at conference in "Cemiyet-i Ilmiyeyi Osmaniye". He put forward that letters should be arranged to read-write the easier than arabic alphabets. Some intellectuel people on the other hand, say that arabic letters need to be completely removed the others come to the conclusion that the letters should be arrenged. When Ittihat and Terakki is effective, Enver Pasha tried to find a solution to this problem by making some arrengements in the alphabet with the alphabet called "Enveri". Alphabet discussions stopped during I. World War and Kurtulus War but discussions over letter reform contiuned after proclomation of the republic. Especially in 1924 the speech of Sukru Saracoglu about letter reform brought again on the agenda. Discussions started at TBMM. The supporters and opponents over alphabet reform expressed their views through press outside TBMM. They published various articles and books on this topic, Examining these debates closely, Mustafa Kemal Atatürk put the Revolution into practice when the conditions were met. The implementation of reform had been influential in the increase of literate rate, the revival of media, the modernization of society, the acceleration of cultural change and the establishment of nation consciousness. The aim of this article is to reveal the discussions on letter reform, which has been exacerbated by the declaration of the republic from the Tanzimat period, and to gain a new perspective.
\end{abstract}

Key Words: Letter Reform, Revolution, Discussions at TBMM, Arabic Alphabet, Latin Alphabet

\title{
Giriş
}

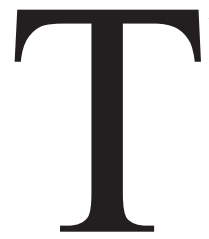

ürk milleti, eski ve köklü bir tarihe sahiptir. Farklı coğrafi bölgelerde siyasi ve sosyal yönden önemli devletler kurmuşlardır. ${ }^{1}$ Türklerin anavatanı Orta Asya'dır. Bölgenin coğrafi özelliklerine göre kültürel ve sosyal hayatlarını şekillendirmişlerdir. Kendilerine özgü yazı ve alfabelerini kullanmışlardır. Orta Asya'dan göç eden Türkler, gittikleri kültürlerden de etkilenmişler farklı yazı ve alfabe kullanmışlardır. Göktürk, Soğut, Uygur, Mani, Kiril, Çin, Tibet, İbrani alfabeleri alfabelerden bazılarıdır. Türklerin İslam dinini kabul etmesiyle Arap Alfabesi kullanılmaya başlanmıştır. ${ }^{2}$

Türkçe, 10. yüzyıldan itibaren Arapça ve Farsça etkisi altında kalmıştır. Arap alfabesinin, Türkçe' ye uyarlanması, yazım kurallarının sürekli değişmesine neden olmuştur. Bu da Türkçe'nin kullanışı ıir dil olmasını engellemiştir. ${ }^{3}$ Türkçe'nin yapısına ve seslerine bu alfabenin uygun olmaması tartışmalara neden olmuştur. Arap alfabesi Türkçe 'deki bazı sesleri karşılamada yetersiz olmuştur. Çünkü Arap alfabesinde ünlü harfler bulunmamaktadır. Ünlü harfler esre, ötre ve üstün işaretleriyle karşılanmaktadır. Bu da Türk dili için yetersiz kalmıştır. ${ }^{4}$

Osmanlı farklı milletlerin bir araya gelerek oluşturulan bir milletti. Osmanlıca içerisindeki Arapça, Farsça kelimelerin artması Türkçe'nin dil olarak gelişmesini engellemiştir. Bu nedenle 19. yüzyılın ikinci yarısında alfabe tartışmaları başlamıştır. ${ }^{5}$ Aydın kesim alfabe sisteminin ıslah edilmesi fikrini Tanzimat'tan Cumhuriyet'e kadar sürekli tartışmışlardır. Cumhuriyet dönemin-

1 Zeynep Korkmaz; "Alfabe Devriminin Türk Toplumu Üzerindeki Sosyal ve Kültürel Etkileri," International Periodical For the Languages, Literature and History of Turkish or Turkic,Volume 4/3, 2009, s.1470.

2 Ayşegül Şentürk; "Harf İnkılabının Yapılışı ve Uygulanışında Basının Rolü”, Süleyman Demirel Üniversitesi Sosyal Bilimler Dergisi, Ağustos 2012, Say1: 26, s.28.; Nurettin Gülmez: "Tanzimat'tan Cumhuriyet'e Harfler Üzerine Tartışmalar," Alfa Aktüel Yayıncılık, İstanbul, 2006, s.,4.

3 Neriman Tongul; “Türk Harf İnk1labı,” Ankara Üniversitesi Türk Inkllâp Tarihi Enstitüsü Atatürk Yolu Dergisi, May1s 2004, Say1: 33-34, s. 103.

4 M. Şakir Ülkütaşır; Atatürk ve Harf Devrimi Ankara, 1973, ss.15-16.

5 Nuran Savaşkan Akdoğan; "Modern Ulus Devlet Olma Yolunda Harf İnkılabı ve Uygulanması", Amme Idaresi Dergisi, C.43, Say1: 3, s. 38. 
de ise harflerin ıslahı yerine harflerin değiştirilip, Avrupa'nın kullandığ Latin harflerinin kabul edilmesi meselesi ön plana çıkmıştır. Basında, kamuoyunda, mecliste ateşli tartışmalar olmuş ve uzun bir süre sonra ancak harf değişikliğine gidilmiştir. Çünkü harf değişikliği için henüz zaman ve zemin oluşmamıştır. Mustafa Kemal, tarafindan azim ve kararlılıkla gerçekleştirilen inkılâplar, kamuoyunun ve basının buna hazırlamasıyla ancak mümkün olmuştur. ${ }^{6}$

Cumhuriyetin ilanı ile ülkenin her kurumunda bir yenilenme ve modernleşme başlamıştır. Bu yenilikler Türkleri batı kültürünü benimsetmek olarak algılanmış olsa da Türk Milletinin varlığını daha iyi tanımasına yardımcı olmuştur. Türklerin Orta Asya'daki eski kültürlerini ve yaşam tarzlarını yeniden ortaya çıkmasını sağlamıştır. Ayrıca Türk Milletinin her alanda diğer toplumlar kadar uygar olduklarını dünyaya duyurulmasını sağlamıştır. Mustafa Kemal, inkılapları ile ülkenin çağdaş medeniyetler seviyesine ulaşmasını amaçlamıştır. ${ }^{7}$

\section{Cumhuriyet Öncesinde Latin alfabesi Tartışmaları}

Bir milletin yüzyıllarca kullandığı alfabeyi değiştirmesi büyük bir olaydır. Bu nedenle ilk başlardan itibaren büyük tartışmalara neden olmuştur. Arap Alfabesinin Kuran yazısı olması, kutsal sayılması ve başka bir alfabeyi almanın dinsizlik olarak algılanacağı ve İslam dünyası ile bağlarının kopacağı düşünülmüştür. ${ }^{8}$ Türkler, İslamiyet'i kabul ettikten sonra aldıkları Arap alfabesini, uzun yıllar kullanmışlardır. Ancak 19. yüzyıldan itibaren tartışmalar başlamıştır. Türklerin Arap Alfabesini kullandıktan sonra Arap ve Fars dillerini etkisi altında bozulmuş, Osmanlıca dilinde Türkçe sözcükler giderek azalmıştır. Osmanlıca yalnızca yabancı sözcüklerle değil yabancı dil kurallarıyla da dolmuştur. Tanzimat'tan itibaren aydınlar harf konusundaki eleştirilerini çeşitli yerlerde ifade etmeye başlamışlardır. 1851 yılında Ahmet Cevdet Paşa, "Kavaid-i Osmaniye" adıyla bir kitap yayınlamıştır. Burada yazı sorununa değinmiştir. Türkçe 'de olan ancak Arap harfleriyle gösterilemeyen sesler için yeni yazım yollarının aranması gerektiğini yazmıştır. Bu soruna değinenlerin bir diğeri de Münif Paşadır. Kurucu üyesi olduğu Cemiyet-i İlmiye-i Osmaniye'de (Osmanlı Bilim Derneği) 12 Mayıs 1862 günü verdiği konferansta bu konuyu dile getirmiştir. ${ }^{9}$ Konferansta şunları ifade etmiştir:

"Arap harfleriyle Türkçe okuyup yazmak zordur. Bu alfabede ünlüler bulunmadığından Türkçe bir sözcük çeşitli biçimlerde okunabilmektedir. Aynı sözcügün beş-altı biçimde okunabildiği olur. Gerçi alışılmış sözcükler doğru olarak okunabilir. Ama anlamları pek bilinmeyen sözcüklerin doğru okunabilmesi hemen hemen olanaksızdır. Arapça ve Farsça sözcüklerle tamlamalar ise okumayı yazmayı büsbütün zorlaştırır. Arap yazısında büyük harfler (Majiskül) bulunmadı̆̆ından öz adlar öteki sözcüklerden ayırt edilemez. Avrupa yazılarında bu gibi güçlükler yoktur. O yazılarla altı- yedi yaşlarındaki çocuklardan uşaklara ve işçilere varıncaya kadar, kadın erkek, herkes kolayca okuma yazma ögrenmektedir. Biz de ise yazımızı ögrenmenin güçlüğü yüzünden halkın eğitimi gerçekleşememektedir. Arap harfleri, kitap, dergi, gazete basımına da hiç elverişli değildir. Başka uluslar otuz kırk harfle istedikleri yapıtları basabiliyorlar. Arap alfabesiyle kitap basabilmek için ise iki üç kat daha çok harf kullanmak gerekir.

6 Emre Yavuz; “Arap Alfabesinden Latin alfabesine Geçiş (Harf inkılâbı 1 Kasım 1928)”,www.academia. edu/9626886/Latin_Alfabesinin_Kabulü_ve_Tartışmalar, s.3.

7 Özgür Mert; “Harf İnkılabının Gerçekleştiği Süreçte Atatürk’ün Tekirdağ Ziyaretinin Basındaki Yansımaları", Çăgdaş Türkiye Tarihi Araştırmaları Dergisi C.17/34,2017,s. 193.

8 Mehmet Tekin; Harf İkılâbı ( Türk Ocaklarının Çalışmaları ve Hatay'da Yeni Yazı), Antakya 1988, s. 23.

9 Sami N. Özerdim; Yazı Devriminin Öyküsü, Türk Dil Kurumu Yayınları(2. Baskı), Ankara, 1994,s. 11.12 . 


\section{Oysa kitap, ĕgitimi yaygınlaştırmanın en güçlü aracıdır. "'10}

Burada ortaya koyulan fikirleri dikkate alan bazı dilciler, bu konuşmayı harf tartışmalarının başlangıcı olarak görmüşlerdir. Azerbaycanlı şair Ahunzade Feth Ali de konferanstan kısa bir süre sonra cemiyete bir tasarı sunmuştur. Tasarı da; “Arap harflerinin kullanılması için dinin bir zorunluluğunun bulunmadığı, Türkçe'nin gelişimini sağlayacak daha kolay bir yazı sisteminin alınabileceğini belirtmiştir. Cemiyet ise asırlardır kullanılan alfabenin değiştirilmesinin mümkün olmadığı sonucuna varmıştır."

Tanzimat döneminde alfabe ıslahı ile başlayıp alfabenin değiştirilmesiyle devam eden tartışmalarda Arap alfabesiyle yaşanan sorunun alfabeden değil eğitimdeki yetersizlikten kaynaklandığ1 düşüncesi yayılmaya başlamıştır. Alfabe değiştirilmesine yönelik gösterilen tepkilerde Arap alfabesinin asla İslam toplumlarının geri kalmasına neden olmadığı bu geriliğin eğitimden kaynaklandığg ve bu alfabenin İslam dünyasındaki birliği sağlayan bir araç olduğu ve kaldırılırsa Osmanlılar ile diğer İslam dünyası arasındaki bağların kopacağı iddia edilmiştir. Örneğin; Namık Kemal Arap harflerinde yapılacak "Islahatın icrasına samimi taraftar" olduğunu ama Arap harflerinin kald1rılmasına da karşı olduğunu vurgulamıştır. Namık Kemal, eğer harfler değiştirilirse gelecek nesil, geniş bir coğrafya da yaşayan ve iki yüz yıllık bir dönemde İslam milliyetinin meydana getirdiği eserleri anlamayacak ve nesillerle milletler arasında bir kopukluk olacağını savunmuştur. Arap harflerinin İslam'1n bütünleştirici gücü olarak kabul etmiştir. ${ }^{12}$ Aydınlardan Ali Suavi ve Şemsettin Sami ise Arap harflerinin sslah edilmesi ile ilgili görüşlerini açıkça ifade etmişlerdir. Arap alfabesi ile ilgili yapılan tartışmalarda harflerin değiştirilmeyip iyileştirilmesi gerektiğini savunanlar çoğunlukta olmuştur. ${ }^{13}$

II. Meşrutiyetin ilanı sonrasında bilim ve düşünce yönündeki atılımlar harfler üzerine tartışmaların çıkmasına da neden olmuştur. Dönemin Maarif Nazırı Şükrü Bey, "Istılahat-1 İlmiye Encümeni” adı altında dört tane encümen kurdurmuştur. Resmi niteliğe sahip bu encümenler, dilbilgisindeki bazı zorlukların giderilmesini sağlamıştır. Bu amaçla; Sarf ve İmlâ Risaleleri, Tedkikat-1 Lisaniye Heyeti’nin Sarf ve İmla Encümeni, Usûl-1 İmla adında eserler yayınlamıştır. İmla (Komisyonu) Encümeni, toplantılarında bazı kararlar almıştır. Bunlar; yeni harfler ve şekiller kabul etmesinin mümkün olmadığını, sesli harflere getirilecek işaretlerin ise sadece ilkokul kitaplarına ve lugat sözlüklerine getirilmesi gerektiğidir. Bu kararlara rağmen imlâ kitaplarında Arapça ve Farsça kelimeler eski şekillerini korumuştur. II. Meşrutiyet Dönemi'nde Arap harflerinin 1slâh edilmesi ile ilgili kurulan cemiyetlerin başında Ta'mim-i Maarif ve Islâh-1 Hurûf Cemiyeti gelmektedir. Bu cemiyete göre; eğitimin yaygınlaşamaması okuma yazma bilenlerin az olması sebebi, harflerin zorluğu ve birleşik yazılmasıdır. Cemiyet üyeleri, Arap harflerini Osmanlıca içerisinde muhafaza edilmesini ancak bazı düzenlemeler yapılması gerektiğini söylemiştir. Harflerin ayrı yazılarak, sesli harflerin kullanılmasını, okuma yazmanın kolaylaştırılması için çalışmalar yapmıştır. ${ }^{14}$

Osmanlıca tartışmaları sürerken, Arnavut Milliyetçileri, 20-26 Ağustos 1909 tarihinde Elbasan kongresinde toplanmışlar. Eğitim dili Arnavutça olmasına ve Latin harflerinin kabul edilmesine karar vermişlerdir. Şeyhülislam Latin Harflerinin kabul edilemeyeceği ile ilgili fetva vermişse de Arnavutlar Latin Alfabesini kabul etmişlerdir. Bu da alfabe tartışmalarının daha da

10 Bilal N. Şimşir; Türk Yazı Devrimi, Türk Tarih Kurumu Yayınları, Ankara, 1992, s. 20.

11 Özerdim; a.g.e.; s.12.

12 Yavuz; a.g.m.; s.8.

13 Cafer Ulu; “Osmanlı'da Alfabe Tartışmaları ve Latin alfabesinin Kabulü Sürecinde Mustafa Kemal’in Çıktığı Yurt Gezileri: Tekirdağ Örneği,” Ankara Üniversitesi Dergisi, s. 279.

14 Muhammet Erat; “Osmanlı'da Alfabe Tartışmaları”, Türkler Dergisi, C:15, s. 155. 
alevlenmesine neden olmuştur. ${ }^{15}$

Enver Paşa, tartışmaların yoğun olduğu dönemde çeşitli sıkıntıları ortadan kaldırmak amacıyla Enveri yazısı dediğimiz, ünlülerin de eklenmiş olduğu ve bitişik olmayan Arap harfleri fikrini ortaya çıkarmıştır. Arap harfleri ayrı yazılarak ve sesli harf eklenerek Latin harflerine benzer şekilde yazılmıştır. Ancak, bu yazı Arap harflerine uymadığı için bu girişim de başarısızlıkla sonuçlanmıştır. Bu yazıya; Ordu Elifbası, Hatt-1 Cedit, Enver Paşa Yazısı gibi isimler verilmiştir. ${ }^{16}$ $\mathrm{Bu}$ dönemde bazı yazarlar harfler üzerinde iyileștirme yapmanın yerine Türkçe'ye daha yakın olabilecek Latin Alfabesine geçilmesini istemişlerdir. Bu yazarlar; Hüseyin Cahit, Abdullah Cevdet, Celal Nuri, Kılıçzade Hakkı, Ziya Gökalp gibi yazarlardır. ${ }^{17}$ Birinci Dünya Savaşı'nın başlamasıyla harf tartışmalarına birkaç yıl ara verilmiştir. ${ }^{18}$

Osmanlı Devleti'nde yaşanan harf tartışmaları esnasında Fransızcanın kullanılması Latin harflerinin bazı kurumlarda kullanmasını da sağlamıştır. Batılı tarzda açılan yeni okullarda, hariciye ile elçiliklerde, bankacılıkta, bürokraside Latin harfleri kullanılmıştır. Tanzimat ile başlayan Harf meselesi Cumhuriyet kurulduktan sonra da tartışma konusu olacaktır. ${ }^{19}$

\section{Cumhuriyet'in İlânı Sonrasında Harf İnkılâbı Üzerine Mecliste Çıkan Tartışmalar ve Karşıt Görüşler}

Birinci Dünya Savaşı'nın getirdiği olağanüstü şartlar sonucunda, alfabe konusu bu dönemde bir canlllık ve gelişme kaydedememiştir. Ancak dünyadaki Türkler Latin alfabesini kullanmaya başlamışlardır. İlk olarak Yakut Türkleri 1918 yılında Latin alfabesini kabul etmiştir. Mustafa Kemal, savaş dönemlerinde de dünyadaki gelişmeleri yakından takip etmiştir. Yapacağı yenilikler ile ilgili planlar oluşturmuştur. Ancak yapacağı devrimlerin zamanı geldiğinde yapılmasını isteyen gerçekçi bir devlet adamıdır. 6 Temmuz 1918'de Karlsbat'ta tedavi olurken hatıra defterine şunları yazmıştır:

"Benim elime büyük salâhiyet ve kudret geçerse ben içtimaî hayatımızda istenilen inkılâbı bir anda bir tahakkuk edeceğimi zannederim... Halkr yeni fikirlerle eğitmek ve öğrenim durumunu yükseltmek gerekir. Aydınlar halkı kendi seviyelerine çıkarmalıdırlar. Bunun anlamı toplumun ögrenimini yeni ve kolay usullerle să̆lamaktır. "20

Erzurum Kongresi'nin düzenlendiği akşam 7-8 Ağustos 1919, Mustafa Kemal, Mazhar Müfid Kansu Bey'i yanına çağırarak ileride, ülkede yapılacak olan inkılâplarla ilgili planlarını anlatmıştır. Latin alfabesi kabul edileceğini de söylemiş̧tir. Mazhar Müfid Bey ümitsiz ve inanmayan bir adam tavrıyla bunların hayal olduğunu söylemiştir. ${ }^{21}$

1922 yllında Azeri Türklerinin Latin alfabesini kabul etmesi bu harflerin getirilmesini isteyenleri Türkiye'de de cesaretlendirmiştir. 12 Eylül 1922 tarihinde İzmir'e bazı gazeteciler gelmiştir. Bunların arasında Hüseyin Cahit Bey de vardır. Hüseyin Cahit Bey ;

"Paşam, Niçin Latin yazısını almıyoruz?"

15 Ramazan Boyacıŏglu; Harf Devrimi ve Sağladĭ̆ı Kolaylıklar, Atatürk Araştırma Merkezi, s.434.

16 Özerdim; a.g.e.; s.13.

17 Ülkütaşır; a.g.e.; s.28.

18 Ulu; a.g.m.; 280.

19 Adem Çelik; Harf Inkılabına Giden Süreç, Marmara Üniversitesi Türkiyat Araştırmaları Enstitüsü, Türk Tarihi Ana Bilim Dalı, Cumhuriyet Tarihi Bilim Dalı, Basılmamış Yüksek Lisans Tezi, İstanbul, 2009, s.19-20.

20 A. Afet İnan, M. Kemal Atatürk'ün Karlsbad Hatıraları, TTK Yayınları, Ankara, 1983, s.43.

21 Mazhar Müfid Kansu; Erzurum'dan Ölümüne Kadar Atatürk'le Beraber, Ankara 1997, s.131. 
sorusuna "Daha zamanı gelmemiştir" diye cevap verir. ${ }^{22}$

Mustafa Kemal, bu anısını daha sonra Falih Rıfkı Atay'a anlatır: "Hüseyin Cahit bana zamansız bir iş yaptırmak istiyordu. Yazı inkılâbının zamanı gelmemişti” demiştir. ${ }^{23}$ Mustafa Kemal, yapmak istediği tüm işlerde önce şartların olgunlaşmasını isteyen bir devlet adamıdır. Hüseyin Cahit' in sorduğu zamanlarda ülkenin böyle bir değişime hazır olmadığını düşünerek gazetecilerle konuşmak istememiştir. ${ }^{24}$

1 Mart 1922'de Mustafa Kemal, TBMM’nin üçüncü toplantı yılını açarken şunları söylemiştir:

"Binaenaleyh, bizim takip edeceğimiz maarif siyasetinin temeli, evvela mevcut cehli izale etmektir. Teferruata girmekten ictinaben bu fikrimi birkaç kelime ile tavzih etmek için diyebilirim ki, genel olarak umum köylüye okumak, yazmak ve vatanını, milletini, dinini, dünyasını tanıtacak kadar coğrafi, tarihi, dini ve ahlaki malûmat vermek ve dört işlemi öğretmek, maarif programımızın ilk hedefidir. " 25

Harf İnkılâbıyla ilgili tartışmalar Cumhuriyet'in ilanı sonrasında da devam etmiştir. 1923 yılında 17 Şubat- 4 Mart tarihleri arasında İzmir'de Milli İktisat Kongresi toplanmıştır. Bu Kongre de kongrenin işçi temsilcilerinden İzmirli Ali Nazmi ve iki arkadaşı tarafindan Latin harflerinin kabulü hakkında kongreye bir teklif verilmiştir. Teklif kongre başkanı Kazım Karabekir tarafından reddedilmiştir. Kazım Karabekir, bu konu ile ilgili düşüncelerinin konudaki görüşlerini, 5 Mart 1923 günü; "Latin Harflerini Kabul Edemeyiz" başlığı altında demeç vererek açıklamıştır. O’na göre; "Latin harflerini savunanlar yabancıların propagandalarından etkilenmekte ve ülkeye zararlı bir fikir sokmaya çalışmaktadırlar. Türk dilini ifade edecek hiçbir Latin harfi yoktur. Bu fikirler Türk toplumunu etkilerse bütün İslâm âlemi üzerimize hücum eder ve birbirimizi yeriz." Sözleriyle ifade etmiştir.

Basına paylaşılan Paşa'nın demeci, alfabe tartışmalarını yeniden başlamasına neden olmuştur. Latin harflerini istemeyenler, yayın çıkarmaya başladılar. Latin harflerini savunanlardan Kılıçzade Hakkı, İçtihad dergisinde, İzmir Kongresinde "Latin Harfleri” başlıklı makale yazarak, Paşa'ya cevap verdi. II. Meşrutiyetten beri Latin alfabesinin getirilmesini savunan Hüseyin Cahit Yalçın'da 22 Eylül 1923 Resimli Gazete de Latin Harfleri, başlıklı yazısında görüşlerini dile getirerek tartışmalara katıldı. 1923 yılında Tahsin Ömer 40 sayfalık bir kitapçık yayınladı. "Harflerimiz Latin Harfleriyle Aynıdır" başlığıyla yayınlanan bu kitapçık Arap ve Latin harflerinin aynı kökten geldiğini Latin alfabesini almanın sakıncalı olmadığını anlattı. ${ }^{26}$

Cumhuriyet dönemi alfabe tartışmaları için de az rastlanan bir fikir de Orhun ve Uygur alfabelerinin yeniden kullanılması olmuştur. Bu fikri savunanlara göre alfabe bir medeniyet işi değil, kültür işidir. Arap ve Latin harfleri bize ana kültürümüzü unutturur. Bunların yerine Türklerin öncelerden kullandığı Orhun veya Uygur harflerinin yeniden kullanılmasının kültürümüz açısından oldukça faydalı olacağını savunmuşlardır. ${ }^{27}$

22 Caner Kerimoğlu; “Hüseyin Cahit Yalçın'ın (1875-1957) Dil İle İlgili Görüşleri,” Çağdaş Türkiye Tarihi Araştırmaları Dergisi, Bahar, 2008, s. 105.

23 Falih Rifkı Atay; "Yeni Yazı", Türk Dili, C: II, Sayı: 23, Ankara, 1 Ağustos 1953, s.718.

24 Cengiz Dönmez; "Atatürk ve Harf İnkılabı,” Atatürk Araştırma Merkezi, s.41.

25 T.B.M.M. Zabıt Ceridesi, Devre I, İçtima Senesi: III, C:12, 1.3.1922, ss. 2-16.

26 Şimşir, a.g.e.,ss. 59-61.

27 Yasemin Kıroğlu; Harf İnkllabının Atatürk Devrimlerinin Yayılmasına Etkisi, Marmara Üniversitesi, Türkiyat Araştırmaları Enstitüsü, Atatürk İlke ve İnkılap Tarihi Anabilim Dalı, Yayınlanmamış Yükseklisans Tezi, İstanbul, 2008, s. 10. 
Basın üzerinden tartışmalar devam ederken mecliste de tartışmalar yeniden başladı. 26 Ağustos 1923'te Bolu/Zonguldak Mebusu Tunalı Hilmi Bey, Meclis Başkanlığı'na “Türkçe Kanunu" adında on maddelik bir kanun teklifi verdi. Bu teklifte, Maarif Vekilliğinin bir komisyon kurmasını yabancı kelimelerin Türkçeleşmesini, okul kitaplarının, gazete ve dergilerin Türkçeye uygun bir şekilde yazılması gerektiği yazılmıştır. Ancak bu teklif İslam birliğini bozacağı gerekçesiyle reddedilmiştir. ${ }^{28}$

Bu tekliften 1 yıl sonra 25 Şubat 1924 tarihinde TBMM'de Bütçe Kanunu Tasarısı görüşülürken söz alan İzmir mebusu Şükrü Saraçoğlu, ülkedeki okuma yazma oranının düşük olmasının nedenini Arap alfabesinin Türkçe için yetersiz olmasına bağladı ve düşüncelerini şu şekilde ifade etti;

Benim kanaatimce, bu büyük derdin en vahim noktası harflerdir. Eğer ben Arap harfi diyecek olursam burada da acaba benim fikrime tuğyan ve isyan edecek var mı? Efendiler! Bunun yegâne kabahatlisi harflerdir. Arap hurufatı Türk lisanını yazmaya müsait değildir. Hacımızın, hocamızın, amirimizin, memurumuzun gayretine, asırlardan beri yapılan bunca fedakârlıklarına rağmen, halkımızın ancak yüzde ikisi veya yüzde üçü okumuştur. ... Ben isterdim ki, tedrisat-1 aliyye ve orta tedrisat için bütçesinin binde yüzünden fazla bir meblağını tahsis eden bu millet pek az bir zaman zarfında çocuklarının okuyup yazmasını görsünler... ${ }^{29}$

Şükrü Saraçoğlu bu konuşması mecliste bazı vekillerin tepkisini çekmiş, tartışmalara neden olmuştur. Mecliste başlayan tartışmalar basına da yansımıştır. ${ }^{30}$ Hüseyin Cahit Bey, yayınladığı "Necat Yolu" başlıklı makalesinde İzmir Mebusu Şükrü Saraçoğlu'nun teklifini olumlu karşılar ve "....Bilâ tereddüt söyleyebiliriz ki, bu bizim için necat yolu olacaktır. Türk milleti ancak şu asırda cehaleti atmakla kendini kurtarabilir. Maarifi en kolay, en çabuk surette neşir ve ta'mîm etmenin yegâne çaresi Latin harflerini kabul etmekten ibarettir" diyerek Şükrü Bey'i desteklemiştir. 3 Mart 1924 tarihinde Tevhid-i Tedrisat Kanunu'nun kabul edilmesiyle, tüm eğitim-öğretim kurumları Milli Eğitim Bakanlığı çatısı altında birleştirilmişsir. Tevhid-i Tedrisat Kanunu'nun kabul edilmesi Harf Devrimini destekleyenleri cesaretlenmiş ve bu konuyu tekrar gündeme getirmişlerdir. 6 Mart 1924 tarihinde Hüseyin Cahit, "Latin Harfleri”" başlıklı yazısında;

"Tedrisat esası ile memleketi kurtarmak hususunda, en emin hatveyi atan Cumhuriyet, Latin harflerini de kabul ederse, tedrisatın bihakkın semeredâr olmasını ve az vakit içinde memlekette büyük bir terakki-i manevî vücûda gelmesini temin edecektir. Yegâne necat yolu bundan ibaret olmasına rağmen, bazı arkadaşların Latin harflerine taraftar olmadıklarını görüyorum.” Cümlelerine yer vermiştir.

İbrahim Alaettin Gövsa ise Hüseyin Cahit'in söylediklerine karşı çıkarak Resimli Gazete de "Harflerimizin Kabahati”" başlığıyla bir yazı yazar. Latin alfabesinin cehaleti alamayacağını ve toplumun yazının değiştirilmesine karşı olduklarını söyler. Ahmet Hikmet Bey "Gönül Hanım" adlı eserinde Harf İnkılabına karşı olduğunu ifade eder. ${ }^{31} 1924$ yılı içerisinde gazetelerde tüm bu tartışmaların olduğu sırada Ali Seydi, "Latin Harfleri Lisanımıza Kabil-i Tatbik midir?" adıyla bir kitapçık yayınlamıştır. Kitapçıkta 3 farklı öneri sunmuştur. Kısaca kitapta;

"Latin alfabesinin kabul edilmesiyle eski kültür birikimlerinin Latin harflerine çevirmek uzun yıllar alacak çocukların kitapsız, kütüphanesiz, rehbersiz, malumatsız kör cahil olarak yetişeceklerdir. Çünkü Latin harfleriyle yazılmış, basılmış Türkçe kitap bulamayacaklardır. Latin

28 TBMM. Zabıt Ceridesi, Devre II, İçtima Senesi I, 26.8.1924, s.295.

29 T.B.M.M. Zabıt Ceridesi, Devre I. İçtima Senesi: I, C:5, 25.2.1340, ss. 335-336.

30 Ulu; a.g.m.; 283.

31 Çelik; a.g.t; ss.45-46. 
Harfleri kabul edilirse dünya üzerindeki Türklerle ve Müslümanlarla irtibat kopar. Latin alfabesi yabancı alfabeler içinde en kısır olanıdır. Türkçe'nin seslerini karşılamaz. Karşılasın diye yeni eklemeler, işaretler katılacaksa bunu Arap harflerini 1slah ederek daha güzel bir şekilde yaparız." ${ }_{32}$

İfadeleri yer almaktadır. 1924'te Türkiye'de harf tartışmaları ülke dışında da farklı görüşler sunularak takip eder. Berlin'deki Türk öğrencileri Bekir Sıtkı Ozansoy başkanlığında Latin harflerinin kabulünü isteyen bir dernek kurmuşlar ve "Yeni Yazı" adıyla dergi çıkarmışlardır. ${ }^{33}$ Bulgaristan Türk Basını da bu tartışmalara katılır. Bulgaristan Türk Öğretmenlerinin sözcülügünü yapan "Bulgaristan Muallimini İslamiye Cemiyeti İttihadiyesi" kendi yayın organı olan Bulgaristan Türk Muallimler Mecmuasında bu konuya yer vererek Latin alfabesini savunanlara da karşı çıkanlarında düşüncelerini yayınlamıştır. ${ }^{34}$

1924 yılında Maarif Vekili iken Saruhan Mebusu olan Çınar Bey öğretmenler arasında bir anket yapmıştır. Türkiye'deki öğretmenlerin \% 97'si Latin Harflerinin alınmaması yönünde düşünce belirtmişlerdir. Bu sonuçla Maarif Nezareti tarafından yüreklendirici bir sonuç ortaya çıkmamıştır. ${ }^{35}$

1925 yılı alfabe tartışmaları bakımından biraz sönük geçmiştir. 25 Şubat 1925'te TBMM'de Milli Eğitim Bütçesi görüşülürken Milli Eğitim Bakanı olan Şükrü Saraçoğlu'na, harfler sorunu konusunda fikri sorulur. Saraçoğlu şu cevabı verir; "Efendiler, Bendeniz Maarif vekiliyim ve Maarif vekili olmak hasebiyle memleketimizde harfler hakkında birçok cereyanlar olduğu için bu cereyanlardan herhangi birisine kuvvet verecek bir şekilde bu millet kürsüsünde söz söylemeyi faydalı değil, zararlı görüyorum... "”,

1925 yılı doğuda Şeyh Sait İsyanının başladığı, Terakkiperver Cumhuriyet Partisi'nin kurulduğu dönemde Şükrü Saraçoğlu, TBMM içinde yazı devrimi üzerine tartışmanın doğru olmadığını düşünerek yatıştırmaya çalışmıştır. 1925 yılı basın hayatında Latin harfleri üzerine durgun geçse de İstanbul Üniversitesi hocalarından Avram Galanti, "Türkçe'de Arabi ve Latin Harfleri ve İmla Meseleleri”" adlı eseriyle, Latin alfabesinin alınmasına karşı çıkmıştır. ${ }^{37}$

Türkiye'de Lâtin alfabesi ile ilgili tartışmalar 26 Şubat-6 Mart 1926'da Bakü'de toplanan I. Türkoloji Kongresi'yle tekrar başlamıştır. Kongreye dünyanın çeşitli yerlerinden gelen 71 Türkolog katılmıştır. Türkiye'den ise Fuat Köprülü başkanlığında bir heyet katılmıştır. Kongrede alınan kararlar Falih Rıfkı, Lâtin harfleri makalesinde; çok önemli bir hadise olarak değerlendirmiş. Avram Galanti ise; "Bakü Türkoloji Kongresinin Gayri İlmî Bir Kararı” başlıklı yazısında "Bakü Kongresi'nin ıstılah hakkında verdiği karar, lisanımızı fakirleştirmekten başka bir şeye yaramaz" diyerek Azerbaycan'ın Latin harflerini almasına karşı çıkmıştır. "Hayat Mecmuasındaki Lâtin Harfleri Meselesi” adlı makalede harf değişikliğini ile ilgili düşünceler beyan edilmiştir. Makalede; yüzyıllardır kullanılan bir milletin yazısının bir anda değiştirilemeyeceği ve Latin harfleri alınacaksa Arap harflerinin yanında ikinci dil olarak alınabileceği gibi görüşler sunulmuştur. ${ }^{38}$ Mehmet Fuat Köprülü'nün de Latin harflerinin karşısında bir duruş sergilemesi bu konuyu daha fazla gündemde tutmuştur. Özellikle kongre bitip Mehmet Fuat Köprülü Türkiye'ye döndükten sonra Türk Ocağı gibi derneklerde Latin harfleri aleyhinde birkaç konuşma yapmış, ardından da

32 Sami N. Özerdim; Yazı Devrimi (Yazı Devrimini Kavrayamayanlar), Türk Dil Kurumu Yayınları, Ankara, 1979, ss. 71-73.

33 Çelik; a.g.t; s.50.

34 Şimşir, a.g.e., s.64.

35 Gülmez; a.g.e., s. 182.

36 T.B.M.M. Zabıt Ceridesi, Devre: II. İçtima Senesi: II. C:14, 25.2.1925, s. 324.-336.

37 Şimşir, a.g.e., s.70.

38 Ulu; a.g.m.; 283. 
çok çeşitli gazete yazıları ve makaleler çıkmış, tepkiler almıştır. ${ }^{39}$

1926 yılında Dr. Kühne Latin alfabesi ile ilgili bir rapor hazırlar. Bu raporda:

“Okuyup yazmak öğrenmek için oldukça uzun bir zaman harcanması gerektiği dikkati çekmiştir. Yazı tekniği yalnız öğretim meselesi olmayıp aynı zamanda birinci derecede bir uygarlık siyaseti meselesidir. Türkler de kendilerine oldukça yakın olan Macar ve Fin lisanlarında yapıldığg gibi bir transkripsiyon kabul ederek hiç şüphesiz Batı uygarlığına katılmak işini kolaylaştırmış olurlar."

Bu rapor Mustafa Kemal Atatürk'ü çok etkilemiştir. Raporun ardından Macar alfabesini incelemeye başlamıştır. ${ }^{40} 22$ Mart 1926 günü TBMM' de Maarif Teşkilatı Kanunu görüşülürken Maarif Vekili Mustafa Necati Bey şu konuşmaları yapar. "Latin hurufu meselesi doğrudan doğruya Devletin siyasi meselesidir. Deruhte ettiğim meselenin başından sonuna kadar ihtiyacımıza mutabık olduğuna kanaat etmezsem ve onun etrafinda tetkikatımı yapmazsam o meseleyi kabul etmem. Herhangi bir meseleyi tetkik etmeden kabul edecek arkadaşınız değilim ... " ${ }_{41}$

Bu konuşma sonrasında Akşam gazetesinde bir anket düzenlenir. Türk aydınlarına bazı sorular sorulur. Bu sorular: Latin harflerini kabul etmeli miyiz? Kabul edersek menfaatlerimiz ne olur? Bu mesele etrafindaki nokta-i nazarınızı lütfeder misiniz? Bu soruları 16 kişi cevaplamıştır. Sadece 3 kişi Latin harflerinin alınmasından yana olduğunu bildirmiştir. ${ }^{42}$ Dönemin başbakanı İsmet İnönü Latin harfleri konusunda kararsızdı. Böyle bir kararı vermenin ağır ve dikkatli olunması gerektiğini söylemiştir. Latin alfabesini geçişin de ve uygulanmasındaki zorluklar olacağını düşünmüştür. 1926 yılında Latin alfabesini savunanların ise sabrı kalmamıştır. Mithat Sadullah, "Latin Harfleriyle Türkçe Elifba Tecrübesi” isminde kitap yayınlamıştır. Hidayet İsmail ise "Arap ve Latin Harfleri” adlı kitapçık yayınlamıştır. ${ }^{43}$ Bakû Kongresi sonrası yapılan çalışmalarda Karaçay Balkar bölgesinde bulunan Türkler de Latin harflerini kabul etmiştir. Böylece harflerin Türkler arasında ayrılık yaratacağ düşünceleri de zayıflamıştır. ${ }^{44}$

Cumhuriyet'in ilan edilmesiyle Mustafa Kemal tarafından başlatılan çağdaş devlet yapılanmasına ve milli devlet sistemine geçiş çalışmaları ile siyasi, sosyal ve kültürel alanda yapılan yenilikler Latin alfabesine geçişi kolaylaştırmıştır. Her yapılan bir inkılâp diğer yapılacak inkılâbın oluşmasına ortam hazırlamıştır. ${ }^{45}$

Türkiye'de Uluslararası Latin Rakamlarının kabul edilmesi Latin alfabesinin kabul edilmesine giden yolda önemli bir adım olmuştur. Erzincan Mebusu Saffet Arıkan, Çorum Mebusu Mustafa Cantekin, Kocaeli Mebusu Reşit Saffet Atabinen ve Balıkesir Mebusu Sadık Deniz tarafından 8 Mayıs 1928 tarihli Uluslararası Rakamların kabulü için kanun teklifi sunmuşlardır. Teklifte; dünyadaki birçok devletle sosyal ve ekonomik ilişkileri olan Türkiye'de sayı şekillerinin kullanılmasının gerekli olduğu ifade edilmiştir. Okullarda kullanılan bu sayıların kanun teklifinin kabul

39 Ali İhsan İlhan; 1925-1928 Yılları Arasında Cumhuriyet ve İkdam Gazetesinde Çıan Harf Inkılabıyla İlgili Konular, Fatih Üniversitesi, Sosyal Bilimler Üniversitesi, Türk Dili ve Edebiyatı Ana Bilim Dalı, Yayınlanmamış Yükseklisans tezi, Haziran 2010, s. 33.

40 Şimşir, a.g.e., s.74.

41 T.B.M.M. Zabıt Ceridesi, Devre, II. İçtima Senesi, III, C:23, 22.3.1926, s. 270-273.

42 Şimşir, a.g.e., s.75.

43 Şimşir, a.g.e., ss.83-84.

44 Mustafa Albayrak; "Yeni Türk Alfabesinin Kabulü Öncesinde Halk Eğitimi ve Yazı Değişimi Konusunda Türk Kamuoyunda Bazı Tartışmalar ve Millet Mekteplerinin Açılması (1862-1928)”, Atatürk Yolu, Ankara,1989, s. 482.

45 Kiroğlu; a.g.t., s. 14. 
edilmesini önermişlerdir. ${ }^{46}$ Urfa Mebusu Refet Bey mecliste söz alarak şu konuşmayı yapmıştır:

"Bu kanunun kabul etmeyi arzu ettiği rakamlar, bütün medeni milletlerce kabul edilmiş rakamlardır... Bütün medeni milletlerin kabul ettikleri, en iyi usûlleri, gelişme ve yükselme yolunda ilerlemek isteyen bütün milletler pervasızca kabul etmektedirler. Bu rakamlar esas itibariyle Doğu'da uzun müddet kullanılmış, bilahare Batı'ya intikal etmiş, orada rakamlar üzerinde 1slah ve güzellik yapılmış olan rakamlardır ki, bunu kabul etmek bizim için en zaruri, en mübrem ve en iyi bir usul olacaktır..."

Öte yandan Kastamonu Mebusu Hasan Fehmi Bey, İsmet Paşa hükümetine şunu soruyordu: "Bir müddet evvel uluslararası tarihi kabul etmiştik. Bilmem o gün, neden bu beynelmilel rakamları kabul etmedik? Bugün beynelmilel rakamları kabul ediyoruz. Oyumuzu vereceğiz. Acaba hükümetimiz beynelmilel harflerin kabulünde ne mahzur görüyor. Bu cihet hakkında hükümet izahat versin?" diye soruyordu.

Bu sözler alkışlarla karşılandı.

Bitlis mebusu Muhiddin Nami Bey’de; “Aynı soruyu sorarak uluslararası rakamların küçük bir parçay meydana getirdiğini, asıl bir bütün olan iktisat, fen, ilim ve medeniyet sahasında gelişmemize büyük bir adım, büyük bir hamle teşkil edecek olan uluslararası harfleri ne zaman kabul edeceğiz? demekteydi.

Latin harflerinin, gelecek toplantı yılında ilk önce kabul edilmesini temenni ediyordu.

Aynı sorulara İzmir Mebusu Maarif Vekili Mustafa Necati Bey’de;

"Bu işte biraz geç kaltyorsak, teşkil ettiğimiz komisyonun, Encümenin faaliyetinin neticesine muntazır olduğumuzdandır. Hurufat meselesi en kısa zamanda tabiatılla medeniyet âleminin kabul etmiş olduğu esaslar dâhilinde halledilecektir. Fakat suhuletle tatbik etmek mecburiyeti de hükümetimiz üzerinde ağır bir vazife olarak bulunmaktadır. Onun için heyet-i aliyeniz mutmain olmalıdır. Hükümetiniz mütehassis encümenlerin, komisyonların faaliyetini mütemadiyen teşvik etmekte ve yakın bir zamanda kabiliyet-i tatbikiyeyi haiz olarak getireceği hurufatı herhalde uzun zaman bekletmeden heyet-i aliyenize takdim edecek bir şekilde çalışmaktadır. Arkadaşlar, maarif vekili sıfatıyla Hasan Fehmi Bey üstadımız tarafindan vuku bulan suale cevap vermek mecburiyetindeyim. Heyet-i aliyenizin gerek bütçede kabul ettiğimiz bir esasla ve gerek vuku bulan tasrihatla hurûfat meselesinin üzerinde, hükümetin nazarl dikkatini celb etmiş ve bu işe ait olan esasat ibraz etmeyi emretmesinde zaten bu işle iştigal eden arkadaşlarımız bu iş etrafinda çalışmışlardır. Yalnız herhangi bir büyük meselenin halli için, tabii zamana ihtiyaç bulunmakla beraber tatbikat sahasında lâzım gelen teshilâtiira'e etmek tam ve kâmil olarak tatbik etmek mecburiyeti vardır." diyerek, cevap veriyordu" 47

Sözleriyle konuya dâhil oluyordu.

Bu konuşmalardan kısa bir süre sonra 20 Mayıs 1928 tarihinde, 1233 sayılı yasayla mecliste Uluslararası Rakamlar kabul edilmiştir. ${ }^{48} 20$ Mayıs 1928 günü toplanan Bakanlar Kurulunda, alfabe konusunu ele alınmıştır. Bu konudaki görüşleri incelemek ve araştırma yapılması için "Dil Encümeni”" adlı bir komisyon kurulmasına karar verilmiştir. Komisyon üyeleri şu şekildedir: Falih Rıfkı, Ruşen Eşref, Yakup Kadri, Mehmet Emin Erişingil, İhsan Sungu, Avni Başman, Ragıp

46 Mahmut Goloğlu; Türkiye Cumhuriyeti Tarihi I (1924-1930) Devrimler ve Tepkileri, Türkiye İş Bankas1 Kültür Yayınları, İstanbul, 2007, s. 273.

47 T.B.M.M. Zabıt Ceridesi, Devre III. İçtima Senesi I, C:4, 8.5.2.1928, s. 226-230.

48 T.B.M.M. Zabıt Ceridesi, Devre III. İçtima Senesi I, C:4, 20.5.1928, s. 205-206. 
Hulusi Özden, İbrahim Grandi, Ahmet Cevat Emre'dir. Daha sonra Fazıl Ahmet, İbrahim Necmi, Ahmet Rasim, Celal Sahir ve İsmail Hikmet gibi kişilerde çalışmalara katılmıştır. Alfabe komisyonu hazırladığı raporda çalışma şekillerini ve toplanma amaçlarını;

"Latin harflerinin lisanımıza tatbiki imkânını düşünmek üzere teşekkül edip, 26 Haziran 1928 'de çalışmasına başlamış olan heyetimiz, doğrudan doğruya bugünkü müşterek ve edebi lisanımızın dayandı̆̆ ince ve mütekâmil İstanbul konuşma dilini esas alarak, bu dile teorik ve fiili yönlerden en uygun ve en elverişli bir alfabe vücuda getirmeye çallşmak ve bu maksatla ilk önce Latin harflerinin asli değerlerini ve kullanıldıkları Avrupa milletleri tarafindan yapılan değişiklikleri tetkik ederek, bugün adı geçen harfleri Türkçe 'ye nasıl tatbik etmenin uygun olacağını azami dikkat ve itina ile düşünmek, sonra da bazı kurallar tespit ederek, bunların mümkün olduğu kadar metodik bir tarzda tatbiki suretiyle bir sonuca varmaktır."

şeklinde sıralanmıştır. Dünya üzerinde Latin alfabesi kullanan İngiliz, Fransız, Alman ve Macar gibi milletlerin alfabeleri teker teker tetkik edilmeye çalışılmış, Latin harflerinin Türkçe'ye tatbiki amacıyla Türkler ve yabancılar tarafından Dil Komisyonuna gönderilen teklifler dikkatle incelenmiştir. Dilimiz için gerekli olan harfler seçilirken; Türkçemizin milli ses bünyesine uymasına, dilimizin ihtiyaçlarının her şeyin üzerinde tutulmasına, İstanbul şivesine uygun olmasına, bütün kelimelerin söylendiği gibi yazılmasına, harflerin hiçbir karışıklı̆ga yol açmamasına Dil Komisyonu özellikle dikkat etmiştir. Komisyon, iki rapor hazırlamış; biri Ahmet Cevat raportörlüğündeki Türkçe'nin Grameri Raporu diğeri ise İbrahim Grandi raportörlüğündeki Elifba Raporu'dur. Bu rapor; Cumhurbaşkanı Mustafa Kemal'e Dolmabahçe Sarayı'nda sunulmuştur. Bu rapor, alfabe üzerine çalışılan ilk resmi ve bilimsel rapor özelliği taşımıştır. Elifba Raporunun sonunda Falih Rıfkı, Ahmet Cevat, İbrahim, Yakup Kadri ve Mehmet İhsan Beyler 'in isimleri yer almaktadır. ${ }^{49} 41$ sayfalık Elifba Raporundaki bölümler şunlardır;

"1. Türk dilindeki seslerin miktar ve keyfiyetleri

2. Latin harflerinin savti klymetleri

3. Avrupa'da kullanılan Latin asıllı alfabelerdeki harfler: Latin, İspanyol, Fransiz, Portekiz, Ingiliz, Alman, Azebaycan, Fin, Macar vb.

4. Bu alfabelerdeki harflerin şekilleri ve savti klymetleri

5. Türkçeye mahsus Latin harflerinin seçilmesi ve bu konuda uyulan esaslar

6. Muhtelif harflerdeki çift harfler, işaretli harfler, Latin alfabesine eklenmiş harfler

7. Türk alfabesini teşkil eden harflerin çeşitli dillerde karşıllkları

8. Tespit edilen yani alfabenin vasıflart, dilimizin bünyesine uygun gelme, ses unsurları arasinda iltibasa yer vermeme, diğer seslerle olan tenazuru muhafaza etme, tamamiyla ulusal olma, gerek okuma ve gerekse yazma konusunda sade, açı ve kolay olma, klişe halinde olmama, imlâda iltibası kaldırma, bedî̀ olma... ${ }^{50}$

Mustafa Kemal alfabe raporunu inceledikten sonra, Falih Rifkı'ya sordu: "Yeni yazlyı tatbik etmek için ne düşündünüz?

Falih Rıfk1: "Bir on beş yıllık uzun, bir de beş yıllık kısa mühletli iki teklif var... Teklif sa-

49 Çelik; a.g.t ,s.81.; Tongul,a.g.m.,s.120.

50 Ülkütaşır, a.g.e., s.61. 
hiplerine göre, ilk devirler iki yazı bir arada öğretilecektir. Gazeteler yarım sütundan başlayarak yavaş yavaş yeni yazılı kısmı artıracaklardır. Daireler ve yüksek mektepler için de tedrici bazı usuller düşünülmüştür. "Yüzüme baktı:

Bu ya üç ayda olur, ya hiç olmaz, dedi.

Hayli radikal bir inkılâpçı iken, ben bile yüzüne bakakalmıştım.

“Çocuğum, Gazetelerde yarım sütun eski yazı kaldığı zaman dahi, herkes bu eski yazılı parçayı okuyacaktır. Arada bir harp, bir iç buhran, bir terslik oldu mu, bizim yazı da Enver'in yazısina döner. Hemen terk olunuverir"'. dedi.. ${ }^{51}$

Konunun yeterince olgunlaştığını gören Mustafa Kemal Atatürk, harekete geçmenin vakti geldiğini düşünmüştür. 9 Ağustos 1928 günü CHP'nin Sarayburnu Parkı'nda düzenlenen eğlencede, harf inkılabının getirileceğini halka bizzat kendisi duyurmuştur. Harf inkılâbı ile ilgili düşüncelerini uzun uzun halka anlatmıştır.

"Sevgili Kardeşlerim;

Huzurunuzda ne kadar bahtiyar olduğumu izah edemem. Duygularımı tek tek kelimelerle ifade edeceğim: Memnunum, mütehassisım, mesudum. Bu vaziyetin bana ilham ettiği hissiyatı huzurunuzda ufak notlar halinde tespit ettim. Bunlart içinizden bir vatandaşa okutacağım."

Diyerek hazırladığı notlarını bir gencin okumasını istemiştir.

"Vatandaşlar, bu notlarım asıl, hakiki Türk kelimeleri, Türk harfleriyle yazılmıştır. Kardeşiniz bunu derhal okumaya teşebbüs etti; birdenbire okuyamad. Biraz çalıştıktan sonra şüphesiz okuyabilir. İsterim ki bunu hepiniz beş-on gün içinde ögrenesiniz. Arkadaşlar, bizim ahenkdar, zengin lisanımız, yeni Türk harfleriyle kendini gösterecektir. Asırlardan beri kafalarımızı demir çerçeve içinde bulundurarak, anlaşılmayan ve anlayamadığımız işaretlerden kendimizi kurtarmak, bunu anlamak mecburiyetindesiniz. Anladığınızın âsarına yakın zamanda bütün kâinat şahit olacaktır. Buna kat'iyetle eminim. Yeni Türk alfabesiyle yazdı̆̆ım bu notları bir arkadaşa okutacağım, dinleyiniz."

Paşa, elindeki notları bu kez Falih Rıfkı'nın okumasını istemiştir. Ardından sözü tekrar alarak konuşmasına devam etmiştir.

"Vatandaşlar, Arkadaşlar! Çok söz, uzun söz bir şey için söylenir, hakikati anlamayanları hakikate getirmek için... Ben bu devirleri geçirdim, şimdi sözden ziyade iş zamanıdır. Artık benim için, hepimiz için çok söz söylemeye ihtiyaç kalmadı kanaatindeyim. Bundan sonra bizim için faaliyet, hareket ve yürümek lâzımdır. Çok işler yapılmıştır amma bugün yapmaya mecbur olduğumuz son değil, lâkin çok lüzumlu bir iş daha vardır: Yeni Türk harflerini çabuk ögrenmelidir. Vatandaşa, kadına, erkeğe, hamala, sandalcıya öğretiniz. Bunu, vatanperverlik ve milletperverlik vazifesi biliniz. Bu vazifeyi yaparken düşününüz ki, bir milletin, bir heyet-i içtimaiyenin yüzde onu okuma-yazma bilir, yüzde doksanı bilmez nevidendir. Bundan insan olanlar utanmak lâzımdır. Bu millet utanmak için yaratılmış bir millet değildir. Iftihar etmek için yaratılmış, tarihini iftiharla doldurmuş bir millettir. Fakat milletin yüzde sekseni okuma-yazma bilmiyorsa, bu hata bizde değildir. Türk'ün seciyesini anlamayarak, kafasını birtakım zincirlerle saranlardadır. Artık mazinin hatalarını kökünden temizlemek zamanındayız. Hataların tashih olunmasında bütün vatandaşların faaliyetini isterim. En nihayet bir sene, iki sene içinde

51 Falih Rıfkı Atay; Çankaya, Pozitif Yayıncılık, İstanbul, 1984, s. 440. 
bütün Türk heyet-i içtimaiyesi yeni harfleri öğreneceklerdir. Milletimiz, yazısı ile kafası ile bütün âlem-i medeniyetin yanında olduğunu gösterecektir," ${ }_{52}$

Mustafa Kemal bu konuşmasından sonra, ülkenin her yerinde çalışmalar başlamıştır. Aydın ve halk kesiminden birçok kimse yeni harfleri öğrenmeye başlamıştır. Gazeteler yeni harflerle yayınlanmış. Halka harf tabloları verilerek harfler tanıtılmıştır. Yeni harflerin her semtte her bölgede öğretilmesi için dershaneler açılmıştır. Bu dershaneler için Halk Dershanelerine Mahsus Türk Alfabesi basılmıştır. Birçok kurumda da yeni harfler kullanılmaya başlanmıştır. İstanbul Belediyesi tarafından telefon rehberi yeni alfabe ile basılmıştır. Ticaret Odası imza ve yazışmalarda yeni harfler kullanmıştır. İstanbul'da ve Ankara'da kurslar açılmıştır. Millî Eğitim Bakanlığı'nda açılan kurslara katılan çok sayıda müfettiş, harfleri öğrendikten sonra yurda dağılmış ve yeni harfleri ögrretmenlere öğretmekle sorumlu tutulmuşlardır..$^{53}$

Mustafa Kemal, bütün yaptığı yeniliklerde olduğu gibi Harf İnkılabını başlatmadan önce halka anlatmak ve inkılabı halka mal etmek amacıyla Anadolu'nun çeşitli yerlerinde gezilere çıkmıştır. 23 Ağustos-20 Eylül tarihleri arasında yaklaşık bir ay; Tekirdağ, Bursa, Çanakkale, Sinop, Samsun, Amasya, Tokat, Sivas ve Kayseri illerine geziler düzenlemiş ve halka Başöğretmen unvanıyla bizzat okuma yazma derslerini kendisi vermiştir. ${ }^{54}$

\section{Latin Alfabesinin Kabul Edilmesi}

Mustafa Kemal'in çabalarıyla çok büyük emek harcanmış ve iki ay gibi kısa bir sürede şaşırtıcı derece de büyük ilerlemeler kaydedilmiştir. İnanılmaz bir hızla eski yazıdan yeni yazıya geçilmiştir. Yeni Türk alfabesinin resmen benimsenip yasallaşması için TBMM'nin tatilinin sona ermesi beklenmiştir. Meclis açılır açılmaz Mustafa Kemal Atatürk yazı devrimi ile ilgili düşüncelerini ortaya koymuştur. ${ }^{55} 1$ Kasım 1928 günü Meclise gelen Atatürk, harf konusuna değinen bir konuşma ile meclisteki nutkuna başlayacaktır. Atatürk konuşmasında:

“Aziz arkadaşlarım, Her şeyden evvel her inkişafin yapı taşı olan meseleye temas etmek isterim. Her vasitadan evvel büyük Türk milletine onun bütün emeklerini kısır yapan çorak yol haricinde kolay bir okuma-yazma anahtart vermek lazımdır. Büyük Türk milleti cehaletten az emekle, kısa yoldan ancak kendi güzel ve asil diline kolay uyan böyle bir vasita ile slyrlabilir. Bu okuma yazma anahtarı ancak Latin esasından alınan Türk elifbasıdır. Basit bir tecrübe, Latin esasindan Türk harflerinin Türk diline ne kadar uygun olduğunu, şehirde, köyde yaşı ilerlemiş Türk evlatlarının ne kadar kolay okuyup yazdıklarını, güneş gibi meydana çıkarmıştır. Büyük Millet Meclisi'nin kararlyla Türk harflerinin kat'iyet ve kanuniyet kazanması bu memleketin yükselme mücadelesinde başlı başına bir geçit olacaktır. Milletler ailesine, münevver yetiştirmiş, büyük bir milletin dili olarak elbette girecek olan Türkçe’ ye bu yeni canlılı̆̆ını kazandıracak olan Üçüncü Büyük Millet Meclis, yalnız edebî Türk tarihinde değil, bütün insanlık tarihinde de mümtaz bir sima kalacaktır. Efendiler, Türk harflerinin kabulü ile hepimiz bu memleketin bütün vatanını seven yetişkin evlatlarına mühim bir vazife teveccüh ediyor. Bu vazife milletimizin kâmilen okuyup yazmak için gösterdiği şevk ve aşka bilfiil hizmet ve yardım etmektir. Hepimiz, hususi ve umumî hayatımızda rast geldiğimiz okuyup yazma bilmeyen erkek-kadın her vatandaşımıza yeni harfleri öğretmek için tehalük göstermeliyiz. Bu milletin asırlardan beri his solunmayan bir ihtiyacını birkaç sene içinde tamamen temin etmek, yakında

52 Atatürk'ün Söylev ve Demeçleri I-III (Açıklamalı Dizin ile), Atatürk Araştırma Merkezi, Divan Yayıncilık, 2006, s.373.

53 Özerdim; a.g.e.,s. 16.

54 Ülkütaşır, a.g.e.,ss.113-116.

55 Şimşir, a.g.e., s.208. 
ufuklarda gözlerimizi kamaştıran bir muvaffakiyet görevidir. Hiçbir muzafferiyet hazlarıyla kıyas kabul etmeyen bu muvaffakiyetin hepimiz heyecanı içindeyiz. Vatandaşlarımızı cehaletten kurtaracak sâde muallimliğin vicdani hazzı mevcudiyetimizi işba etmiştir (doyurmuştur). Aziz arkadaşlarım; yüksek ve edebi yadigârımızla büyük Türk milleti, yeni bir nur âlemine girecektir..."

dedikten sonra yeni harflerden örnekler vermiş ve Türk diline en uygun olan harflerin Türk alfabesi olduğu belirtilerek milletvekillerinden yeni harfleri kabul etmelerini isteyerek konuşmasını nihayetlendirmiştir..$^{56}$

Mustafa Kemal konuşmasının ardından Meclis Başkanı Kazım Özalp, üç milletvekili tarafindan verilen önergeyi okuttu. Önergenin kabul edilmesiyle 15 kişilik Geçici Harf Komisyonu oluşturuldu. ${ }^{57}$ Daha sonra hükümet adına konuşan Başbakan İsmet Paşa:

"Türk Alfabesi ile bu milletin okuma yazma mücadelesine girmesi her yan da büyük bir açılma, büyük bir kolaylık doğurmuştur. Hiçbir kanun tasarısı, görüşülürken, kesinlikle uygulanacağına ve büyük sonuçlar getireceğine böylesine güven vermemiştir. Sebebi açıktır. Çünkü böyle bütün bir milletin hayatını, düşünce ve maneviyat hayatını etkileyecek olan temelli bir iyileştirmeye bütün milletin içinde ve her köşede esasll olarak işlenmedikçe, başvurulmak çok cesaret ister. Sizler, bu olay ile memleketin her yanında ne kadar esaslı bir ihtiyaca değindiğinizi açık olarak gördünüz. Milletin tez elden okuyup yazmak, bilgisizlikten sıyrılmak için taşıdiğ istek derin, geniş ve samimidir." 58

Şeklinde sözlerini dile getirdi.

Daha sonra Meclis kürsüsüne Konya milletvekili Refik Koraltan, Mehmet Emin Yurdakul gibi milletvekilleri harf inkılabının yapılması yönünde konuşmalar yapmıştır. Sivas Milletvekili Rahmi Bey ise, gümüşten bir levha üzerine altından yapılmış harflerin Atatürk'e hediye edilmesini istemiş ve bu istek oy birliği ile kabul edilmiştir. ${ }^{59}$

Meclis'te 1 Kasım 1928'de 11 maddelik bu kanun oy birliğiyle kabul edilmiştir. 3 Kasım 1928 yılında Cumhurbaşkanı tarafından imzalanmış ve Resmi Gazetede yayınlanmıştır. ${ }^{60}$ Kanunun Resmi Gazete'de yayınlanmasının ardından bütün devlet dairelerinde, özel kurumlarda, gazete, dergi levha ve reklamlarda yeni harfler kullanıldı. Ocak 1929'dan tüm kitaplar yeni harflerle basıldı ve eğitime yeni harfler öğretilerek devam edildi. Devlet dairelerinde kullanılan kanunlar, yönetmelikler, cetveller, defterler, para, bono, pul gibi kıymetli kâğıtlar değiştirilmesi, evrakların, fezlekelerin, defterlerin yazılması, yazılı dilekçelerin verilmesi içinse Haziran 1929'a kadar süre verilmiştir. ${ }^{61}$

\subsection{Harf İnkılabının Uygulanmaya Başlaması}

Türkiye'de; okuma yazma bilen kişi sayısı şu şekildedir:

1927 yılında okur-yazarlık oranı, kadınlarda \% 4,

Erkeklerde \% 13 ve genel nüfus \% 8.16 dir.

56 T.B.M.M. Zabıt Ceridesi, Devre: III, İçtima Senesi II, C:5, 1.11.1928, s. 3-5.

57 Goloğlu; a.g.e; 281.

58 T.B.M.M. Zabıt Ceridesi, Devre:III. İçtima Senesi II, C:5, 1.11.1928, ss. 7-8.

59 T.B.M.M. Zabıt Ceridesi, Devre:III. İçtima Senesi II, C:5, 1.11.1928, s. 11.

60 T.B.M.M. Zabıt Ceridesi, Devre:III. İçtima Senesi II, C:5, 1.11.1928, s. 6-7.

61 Resmi Gazete, 3.11.1928, no:1030. 
Bunun \% 5-6'sı eski yazıyı bilen Türkler, geri kalanı gayrimüslimlerdir.

Kentlerde okur-yazarlık oran $1 \% 30$, köylerde $\% 6$ civarındadır. ${ }^{62}$

$\mathrm{Bu}$ nedenle hem yeni harflerin öğretilmesi hem de kısa sürede okuryazarlık oranının yükseltilebilmesi için harekete geçilmesi gerekliydi. Bakanlıklar da devlet dairelerindeki memurlara kurslar verilmeye başlandı. Onlar için ders notları ve kitapçık basıldı. Sınav yapıldı ve başarı gösterenlere "Türk harfleri ile okuyup yazabilir" diye bir belge verildi. Devlet yazışmalarını Dışişleri Bakanlığı yeni harflerle karşılık verdi. Gazetelerin yeni harflerle basımını kolaylaştırmak amacıyla çeşitli yardımlar yapıldı. Sokaklarda, gemilerde, tren iskeleleri ve istasyonlarda yeni harflerle isimleri yazıldı. Öğretmenlere yeni yazı öğretilmeye başlandı. Ders kitapları yeni harflerle basıldı. Kitaplar mümkün olduğunca sade Türkçe ile basılmaya özen gösteriliyordu. Türkçe kitapların basılması için matbaalara çeşitli yardımlar yapıldı. ${ }^{63}$

\subsection{Millet Mektepleri Açılması}

Türk Harfleri yasasının yürürlüğe girişinden dört gün sonra 7 Kasım 1928 günü, Başbakan İsmet İnönü T.B.M.M kürsüsünde yaptığı konuşmada Millet Mekteplerinin açılacağını duyurmuştur. Yazı inkılabını sadece devlet görevlilerine, okul çocuklarına yeni yazıyı öğretmekle yetinmeyip, ileri yaşlardaki halka da yeni yazıyı öğretmek için Millet Mektepleri açılmıştır. ${ }^{64}$ Millet Mektepleri, A ve B dershaneleri, halk okuma odaları ve köy yatı dershanelerinden oluşmuştur. Millet Mekteplerinin Başkanı, Mustafa Kemal'dir. Bu mekteplere okula devam edemeyen 16-45 yaş arasındaki tüm vatandaşların katılması zorunludur. Katılan kişiler sınav yapılarak belge verilmiştir. Öğretmeni veya okulu olmayan köylerde ise gidip onlara yeni yazıyı öğretecek Seyyar Talim Heyetleri kurulmuştur. Bu okullar için yeni harflerle hazırlanan kitaplar basılmıştır. Okullarda sadece alfabe öğrenimi değil, Kıraat bilgisi, Yurt bilgisi, Sağlık Bilgisi ve hesap ölçü, tarih, coğrafya gibi derslerde verilmiştir.

Millet Mektepleri halkın eğitim seviyesinin yükselmesini ve bilinçlenmesini de hedeflemiştir. 1928-1935 yılları arasında ülkede, eski harfleri bilen ve hiç okuma bilmeyenler dâhil yeni harflerle yaklaşık 3,5 milyon insana okuma-yazma öğretilmiştir. O dönemde nüfusun dörtte biri okur-yazar duruma gelmiştir. Zamanın şartları ele alındığında çok önemli bir gelişme olduğu açıktır. ${ }^{65} 1935$ yılına gelindiğinde okuma yazma bilen sayısı \%19,9'a yükselmiştir. Erkek nüfus okuma yazma oranı \%29,3'e kadınlar da ise oran \%10,5'e yükselmiştir. Okur-yazar oranının artmasında yeni alfabenin Arap alfabesine göre daha kolay olması ve Türk dilinin ses özelliklerine uygun olması etkili olmuştur. ${ }^{66}$

\section{Sonuç}

Türkler, tarih boyunca çeşitli alfabeler kullanmıştır. İslam dininin kabul edilmesiyle Arap alfabesini kullanmaya başlamışlardır. Ancak zamanla Osmanlıcanın içerisinde Arapça ve Farsça kelimelerin artması, Türkçe' de ki bazı ses ve kelimeleri karşılayamaması Tanzimat döneminde birçok aydın tarafından alfabe konusunda tartışmaların başlamasına neden olmuştur. Bu tartışmalar Cumhuriyet'in ilanı sonrasında da devam etmiştir.

Alfabe konusu, mecliste de uzun zaman tartışma konusu olmuştur. Alfabe karşıtları ve ta-

\footnotetext{
62 Tongul; a.g.m, s.126.

63 Şimşir, a.g.e., ss.216-233.

64 Şimşir, a.g.e., s. 234.

65 Tongul; a.g.m, s.126.; Albayrak; a.g.m., 490.

66 Kıroğlu, a.g.t., s.64.
} 
raftar olanlar meclis dışında da tartışmalarını sürdürmüşlerdir. Alfabe değişikliklerini isteyenler Mustafa Kemal'den hemen geçilmesini istemelerine rağmen şartlar olgunlaşmadan mümkün olmayacağını söylemiştir. Tanzimat'tan beri tartışılan bu konuyu Mustafa Kemal Atatürk, uzun yıllar yakından incelemiş, toplumun ve devletin inkılaba hazır olduğu düşündüğü zamanda gerekli çalışmaları yaparak halkı kendi bilinçlendirmiştir. Yıllardır tartışılan Alfabe konusunu Mustafa Kemal başarmıştır.

Mustafa Kemal'in başarılı olmasında şüphesiz tüm inkılaplarda olduğu gibi plan ve programlı şekilde ilerlemesinin etkisi olmuştur. Bir dilci gibi Latin alfabesinin Türkçe 'ye nasıl uyarlanabileceği üzerine çalışmalar yapmıştır. Çeşitli aydınların bu konudaki görüşlerini alarak yapılacak çalışmalar tasarlanmıştır. Kamuoyunun bu konudaki desteğini de aldıktan sonra harfleri halka bizzat kendi tanıtmıştır. İnkılabın uygulanması sürecini de dikkatle takip etmiştir. Mustafa Kemal Atatürk, Harf İnkılabı ile Türkleri İslamiyet’ten uzaklaştırmanın aksine Türk Milletinin kendi öz Türkçesini ve kültürünü öğrenmesini istemiştir.

Mustafa Kemal Atatürk önderliğinde kabul edilen Latin alfabesi kabulü Türkiye Cumhuriyet'i için bir dönüm noktası olmuştur. Latin alfabesinin kabulünden önce okuma-yazma işi sadece aydın zümrenin elinde bulunurken, harf inkılabıyla beraber halkın her kesimi okur-yazar durumuna gelmiştir. Türk milleti bu inkılâp hareketiyle çağdaşlaşma sürecini hızlandırmıştır. Çağdaş ve modern bir Türkiye hedefi için yapılan bu inkılâp ile halk rahatlıla okuma yazma öğrenebilmiş, gündelik konuşmalarını rahatlıkla yazıya dökebilmiştir. Batı kültürü ile Türk Kültürü arasındaki uyum gösterilmeye çalışılmıştır. Millet Mektepleri Halkevleri ve Halkodaları kurularak okuma-yazma bilmeyenlere okuma-yazma imkânı sunulmuştur. Türk Milletinin eğitim seviyesi yükselmesi sağlanmıştır.

\section{KAYNAKÇA}

\section{Kitaplar}

ATAY, Falih Rıfkı; Çankaya, Pozitif Yayıncılık, İstanbul, 1984.

İNAN, A. Afet, M. Kemal Atatürk'ün Karlsbad Hatıraları, TTK Yayınları, Ankara, 1983.

GOLOĞLU, Mahmut; Türkiye Cumhuriyeti Tarihi I (1924-1930) Devrimler ve Tepkileri, Türkiye İş Bankası Kültür Yayınları, İstanbul, 2007.

GÜLMEZ, Nurettin; Tanzimat'tan Cumhuriyet'e Harfler Üzerine Tartışmalar, Alfa Aktüel Yayıncılık, İstanbul, 2006.

KANSU, Mazhar Müfid; Erzurum'dan Ölümüne Kadar Atatürk'le Beraber, Ankara 1997.

ÖZERDİM, Sami N.; Yazı Devriminin Öyküsü, Türk Dil Kurumu Yayınları (2. Baskı), Ankara, 1994.

ÖZERDİM, Sami N.; Yazı Devrimi (Yazı Devrimini Kavrayamayanlar), Türk Dil Kurumu Yayınları, Ankara, 1979.

ŞİMŞİR, Bilal N.; Türk Yazı Devrimi, Türk Tarih Kurumu Yayınları, Ankara, 1992.

TEKİN, Mehmet; Harf Inkılâbı( Türk Ocaklarının Çalışmaları ve Hatay'da Yeni Yazı), Antakya, 1988.

ÜLKÜTAŞIR, M. Şakir; Atatürk ve Harf Devrimi Ankara, 1973. 
ATATÜRK’ÜN SÖYLEV VE DEMEÇLERİ I-III (Açıklamalı Dizin ile), Atatürk Araştırma Merkezi, Divan Yayınc1lık, 2006.

\section{Makaleler}

ALBAYRAK, Mustafa; "Yeni Türk Alfabesinin Kabulü Öncesinde Halk Eğitimi ve Yazı Değişimi Konusunda Türk Kamuoyunda Bazı Tartışmalar ve Millet Mekteplerinin Açılması (18621928)", Atatürk Yolu, Ankara,1989, ss. 463-495.

AKDOĞAN, Nuran Savaşkan; "Modern Ulus Devlet Olma Yolunda Harf İnkılabı ve Uygulanması”, Amme İdaresi Dergisi, C.43, Say1. 3, 33-59.

ATAY, Falih Rıfkı; "Yeni Yazı", Türk Dili, C: II, Sayı: 23, Ankara 1 Ağustos 1953, 717729.

BOYACIOĞLU, Ramazan; Harf Devrimi ve Sağladı̆̆ı Kolaylıklar, Atatürk Araştırma Merkezi.429-450.

DÖNMEZ, Cengiz; “Atatürk ve Harf İnkılabı”, Atatürk Araştırma Merkezi, 37-70.

ERAT, Muhammet; Osmanlı'da Alfabe Tartışmaları, Türkler Dergisi, C:15, 154-166.

KORKMAZ, Zeynep; “Alfabe Devriminin Türk Toplumu Üzerindeki Sosyal ve Kültürel Etkileri”, International Periodical For the Languages, Literature and History of Turkishor Turkic, Volume 4/3 Spring 2009, 1470-1480.

KERIMMOĞLU, Caner; “Hüseyin Cahit Yalçın'ın (1875-1957) Dil İle İlgili Görüşleri”, Çağdaş Türkiye Tarihi Araştırmaları Dergisi, Bahar 2008, 103-117.

MERT, Özgür; “Harf İnkılabının Gerçekleştiği Süreçte Atatürk'ün Tekirdağ Ziyaretinin Basındaki Yansımaları”, Çă̆daş Türkiye Tarihi Araştırmaları Dergisi Cilt.17/34,2017, 191-204.

ŞENTÜRK, Ayşegül; “Harf İnkılabının Yapılışı ve Uygulanışında Basının Rolü”, Süleyman Demirel Üniversitesi Sosyal Bilimler Dergisi, Ağustos 2012, Say1: 26, 27-44.

TONGUL, Neriman; “Türk Harf İnk1labı”, Ankara Üniversitesi Türk Inkılâp Tarihi Enstitüsü Atatürk Yolu Dergisi, Mayıs 2004, Say1: 33-34, 103-130.

ULU, Cafer; "Osmanlı'da Alfabe Tartışmaları ve Latin alfabesinin Kabulü Sürecinde Mustafa Kemal'in Çıktığg Yurt Gezileri: Tekirdağ Örneği”, 279. Ankara Üniversitesi Dergisi, 77-304.

YAVUZ, Emre; “Arap Alfabesinden Latin alfabesine Geçiş (Harf inkılâbı 1 Kasım 1928)”, www.academia.edu/9626886/Latin_Alfabesinin_Kabulü_ve_Tartışmalar, 1-41.

\section{Tezler}

ÇELİK, Adem; Harf Inkılabına Giden Süreç, Marmara Üniversitesi Türkiyat Araştırmaları Enstitüsü, Türk Tarihi Ana Bilim Dalı, Cumhuriyet Tarihi Bilim Dalı, Basılmamış Yüksek Lisans Tezi, İstanbul, 2009.

İLHAN, Ali İhsan; 1925-1928 Yılları Arasında Cumhuriyet ve İkdam Gazetesinde Çıan Harf Ínkllabıyla İlgili Konular, Fatih Üniversitesi, Sosyal Bilimler Üniversitesi, Türk Dili ve Edebiyatı Ana Bilim Dalı, Yayınlanmamış Yüksek lisans tezi, Haziran 2010.

KIROĞLU, Yasemin; Harf Inkılabının Atatürk Devrimlerinin Yayılmasına Etkisi, Marmara Üniversitesi, Türkiyat Araştırmaları Enstitüsü, Atatürk İlke ve İnkılap Tarihi Anabilim Dalı, Yayınlanmamış Yüksek lisans Tezi, İstanbul, 2008. 


\section{Meclis Kaynakları}

T.B.M.M. Zabıt Ceridesi, Devre I, İçtima Senesi: III, C:12, 1.3.1922, 2-16.

T.B.M.M. Zabıt Ceridesi, Devre II, İçtima Senesi: I, C:1, 26.8.1924, s. 295.

T.B.M.M. Zabıt Ceridesi, Devre, I. İçtima Senesi: I, C:5/1, 25.2.1340, ss. 335-336.

T.B.M.M. Zabıt Ceridesi, Devre, II. İçtima Senesi II, C:14, 25.2.1925, ss. 324.-336.

T.B.M.M. Zabıt Ceridesi, Devre, II. İçtima Senesi III, C:23, 22.3.1926, ss. 270-273.

T.B.M.M. Zabıt Ceridesi, Devre III. İçtima Senesi I, C:4, 8.5.2.1928, ss. 226-230.

T.B.M.M. Zabıt Ceridesi, Devre III. İçtima Senesi I, C:4, 20.5.1928, ss. 205-206.

T.B.M.M. Zabıt Ceridesi, Devre III. İçtima Senesi II, C:5, 1.11.1928, ss. 3-5.

T.B.M.M. Zabıt Ceridesi, Devre III. İçtima Senesi II, C:5, 1.11.1928, ss. 7-8.

T.B.M.M. Zabıt Ceridesi, Devre III. İçtima Senesi II, C:5, 1.11.1928, s. 11.

T.B.M.M. Zabıt Ceridesi, Devre III. İçtima Senesi II, C:5, 1.11.1928, ss. 6-7.

Resmi Gazete, 3.11.1928, no:1030 